\title{
The Evolution of Modern Eukaryotic Phytoplankton
}

\author{
Paul G. Falkowski, ${ }^{1,2 *}$ Miriam E. Katz, ${ }^{2}$ Andrew H. Knoll, ${ }^{3}$ Antonietta Quigg, ${ }^{1} \dagger$ John A. Raven, ${ }^{4}$ Oscar Schofield, ${ }^{1}$ F. J. R. Taylor ${ }^{5}$
}

The community structure and ecological function of contemporary marine ecosystems are critically dependent on eukaryotic phytoplankton. Although numerically inferior to cyanobacteria, these organisms are responsible for the majority of the flux of organic matter to higher trophic levels and the ocean interior. Photosynthetic eukaryotes evolved more than 1.5 billion years ago in the Proterozoic oceans. However, it was not until the Mesozoic Era (251 to 65 million years ago) that the three principal phytoplankton clades that would come to dominate the modern seas rose to ecological prominence. In contrast to their pioneering predecessors, the dinoflagellates, coccolithophores, and diatoms all contain plastids derived from an ancestral red alga by secondary symbiosis. Here we examine the geological, geochemical, and biological processes that contributed to the rise of these three, distantly related, phytoplankton groups.

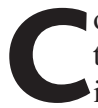
oined in 1897 , the term "phytoplankton" describes a diverse, polyphyletic group of mostly single-celled photosynthetic organisms that drift with the currents in marine and fresh waters (1) (Fig. 1). Although accounting for less than $1 \%$ of Earth's photosynthetic biomass, these microscopic organisms are responsible for more than $45 \%$ of our planet's annual net primary production (2). Whereas on land, photosynthesis is overwhelmingly dominated by a single clade (the Embryophyta) containing nearly 275,000 species, there are fewer than $\sim 25,000$ morphologically defined forms of phytoplankton; however, they are distributed among at least eight major divisions or phyla (Fig. 2). Here we review the macroevolutionary histories of the major phytoplankton taxa that dominate the modern oceans and explore how these evolutionary trajectories have helped to shape the structure of marine ecosystems.

${ }^{1}$ Institute of Marine and Coastal Sciences, Rutgers University, 71 Dudley Road, New Brunswick, NJ 08540, USA. 'Department of Geological Sciences, Rutgers University, Piscataway, NJ 08854, USA. ${ }^{3} \mathrm{De}-$ partment of Organismal and Evolutionary Biology, Harvard University, Cambridge, MA 02138, USA. ${ }^{4} \mathrm{Di}$ vision of Environmental and Applied Biology, University of Dundee at SCRI, Scottish Crop Research Institute, Invergowrie, Dundee DD2 5DA, UK. ${ }^{5}$ Department of Earth and Ocean Science, and Department of Botany, University of British Columbia, 6270 University Boulevard, Vancouver, BC, Canada V6T 1 Z4.

*To whom correspondence should be addressed. Email: falko@imcs.rutgers.edu

†Present address: Department of Marine Biology, Texas A\&M University, Galveston, TX 77551, USA.

\section{Phylogenetic Relationships}

Numerically, the vast majority of phytoplankton in the contemporary oceans is composed of cyanobacteria, the only extant prokaryotic group of oxygenic photoautotrophs. The basic photosynthetic apparatus in all cyanobacteria consists of two photochemical reaction centers, designated Photosystem I (PSI) and PSII (3). PSII oxidizes water and passes the electrons through a cytochrome $\mathrm{b}_{6} / \mathrm{f}$ complex to PSI, while simultaneously creating a cross-membrane proton gradient that is used to generate adenosine $5^{\prime}$-triphosphate (ATP). PSI, operating in series with PSII, generates a biochemical intermediate with a sufficiently low redox potential to drive the enzymatic reduction of $\mathrm{CO}_{2}$ to form organic molecules. Because water provided a virtually infinite supply of reductant for carbon fixation (4), within several hundred million years, oxygenic photoautotrophs spread across the sunlit surface of the planet, making possible the oxidation of Earth's surface oceans and atmosphere $\sim 2.4$ billion years ago (Ga) $(5,6)$.

Oxygenic photosynthesis appears to have evolved only once, but it subsequently spread via endosymbiosis to a wide variety of eukaryotic clades $(7,8)$. The earliest oxygenic photosynthetic eukaryotes are thought to have arisen from the wholesale engulfment of a coccoid cyanobacterium by a eukaryotic host cell that already contained a mitochondrion (9). The engulfed cyanobacterium would become a membrane-bounded organelle called the "plastid." The mitochondrion and plastid are the only two organelles that appear to have been appropriated via endo- symbioses. Gene loss through time essentially reduced both symbionts to metabolic slaves within their host cells.

A schism early in the evolution of oxygenic eukaryotic photoautotrophs gave rise to two major plastid lineages. One group, united by the use of chlorophyll b as an accessory pigment, is overwhelmingly dominated by the green algae and their descendants, the land plants $(10,11)$. Collectively, this "green" plastid lineage is much more closely related by plastid phylogeny and photosynthetic physiology than by the evolutionary history of the host cells. The second lineage includes the red algae (rhodophytes), which retain the most features of cyanobacterial pigmentation, and a diverse set of phytoplankton and seaweeds whose plastids (but again, not their host cells) are evolutionarily derived from rhodophytes $(10,11)$. With the exception of the red algae themselves, members of this "red" plastid lineage utilize chlorophyllide $\mathrm{c}$ and its derivatives as accessory photosynthetic pigments. Of the eight major eukaryotic phytoplankton taxa in the contemporary ocean, all but one possess "red" plastids. In contrast, with the minor exception of some soil-dwelling diatoms and xanthophytes, all terrestrial algae and plants have "green" plastids.

\section{The Fossil Record of Phytoplankton}

The geological record of phytoplankton is inevitably biased toward forms that produce mineralized skeletons or decay-resistant organic walls. Nonetheless, broad features of early phytoplankton diversification can be gleaned from sedimentary rocks, as can a detailed evolutionary record of some skeletonized taxa that appeared later.

Modern cyanobacteria synthesize 2-methylbacteriohopanepolyols (12), and the recovery of their geologically stable derivatives $\left(>\mathrm{C}_{31} \quad 2 \alpha\right.$-methylhopanes) from late Archaean shales (13) suggests that oxygenic photoautotrophs were present in marine ecosystems $2.7 \mathrm{Ga}$, if not earlier (14). Organic walled fossils demonstrably made by eukaryotes and plausibly made by phytoplankton occur in rocks as old as 1.6 to 1.8 billion years (15), but their morphological diversity is low and their phylogenetic relationships obscure. Exceptional fossil populations that 
preserve details of morphogenesis and life cycle indicate that red algae evolved no later than $\sim 1.2 \mathrm{Ga}(16,16 a)$, and the secondary endosymbioses that drove red-lineage diversification appear to have begun soon afterward $(10,11)$. Neoproterozoic fossil assemblages contain fossils assigned to derived clades of green algae (17), supporting inferences from morphology (18) and ultrastucture (19) that members of the green lineage contributed to the eukaryotic phytoplankton.

The organic cyst walls of planktonic algae diversified markedly, in parallel with the Cambrian and Ordovician radiations of marine invertebrates, peaking in the mid-Paleozoic before a sharp Late Devonian decline. Many of these microfossils are difficult to taxonomically classify because they have no extant analogs; however, morphological and ultrastructural features indicate that green algae enjoyed a taxonomic and ecological prominence not seen in oceans of the past 190 million years [(e.g., $(20-22)]$. The only phytoplankton taxa to leave unequivocal evidence of abundance in the Paleozoic are the green tasmanitids, fossil prasinomonads whose phycoma phase is found throughout the Paleozoic and in abundance in Permian deposits of so-called "white coal" in Tasmania and oil-rich early Mesozoic deposits in Alaska $(15,23-25)$. "Red" lineage phytoplankton are recorded in Neoproterozoic and Paleozoic successions by dinoflagellate lipid biosignatures, which in one instance have been linked to distinctively ornamented microfossils (26). Nonetheless, morphologically distinct dinoflagellates are not known with certainty until Mesozoic time.

The rise of a modern eukaryotic phytoplankton community began in the Middle Triassic (Fig. 3), as marine biotas began a sustained recovery from the end-Permian mass extinction. Although they are still well represented in the modern ocean by small ( 1 to $3 \mu \mathrm{m})$ cells, especially in the deep chlorophyll communities, prasinophyte green algal abundances began a long-term decline from the Triassic. In contrast, three new groups entered the fossil record, portending their ecological and taxonomic expansion. The Mesozoic radiation of the dinoflagellates, coccolithophores, and diatoms paralleled a long-term increase in sea level with an accompanying expansion of flooded continental shelf area (Fig. 3). In the modern ocean, these three eukaryotic groups are responsible for the vast majority of the export flux of organic matter to the ocean interior and sediments. All three groups are members of the red lineage (Fig. 3).

The carbonaceous microfossils of dinoflagellates have distinctive walls containing dinosporin, a chemically resistant material resembling sporopollenin. The fossils are relict resting cysts that preserved well in the sediments of shallow continental margins.
They form an extensively studied micropaleontological record that has been exploited for biostratigraphic correlation (especially by oil companies). This record reveals a limited number of morphologically diagnostic dinocysts in later Triassic deposits, followed by a major radiation in the Early Jurassic. Although present in older strata, molecular biomarkers of dinoflagellates (e.g., dinosterol) also show a marked increase in abundance that parallels microfossil diversification $(27,28)$.

Coccolithophorids, a clade within the haptophytes whose members are armored with miniature plates (coccoliths) of calcite (29), also appeared by the Late Triassic (30). Evolutionary turnover in this clade was rapid, making coccoliths a second, excellent stratigraphic marker in marine sediments $(31,32)$.
The origin of diatoms is more obscure. The siliceous cell walls (frustules) that characterize this group of phytoplankton do not preserve well in marine sediments; the silica usually dissolves. Estimates based on the rate of evolution of ribosomal genes (i.e., a molecular "clock") suggest that these organisms originated near the Permian-Triassic boundary (33), but fossil frustules appear only much later in the Mesozoic Era. Rothpletz (1896) reported diatom frustules in Jurassic sediments (34); however, his observations have not been substantiated by later workers, and the type samples appear to have been lost in the Second World War (35). There is clear fossil evidence that diatoms began to radiate by the Early Cretaceous (36). Several species of centric marine diatoms occur in marine sediments dated at 125 million years ago (Ma) (37), and by the end of
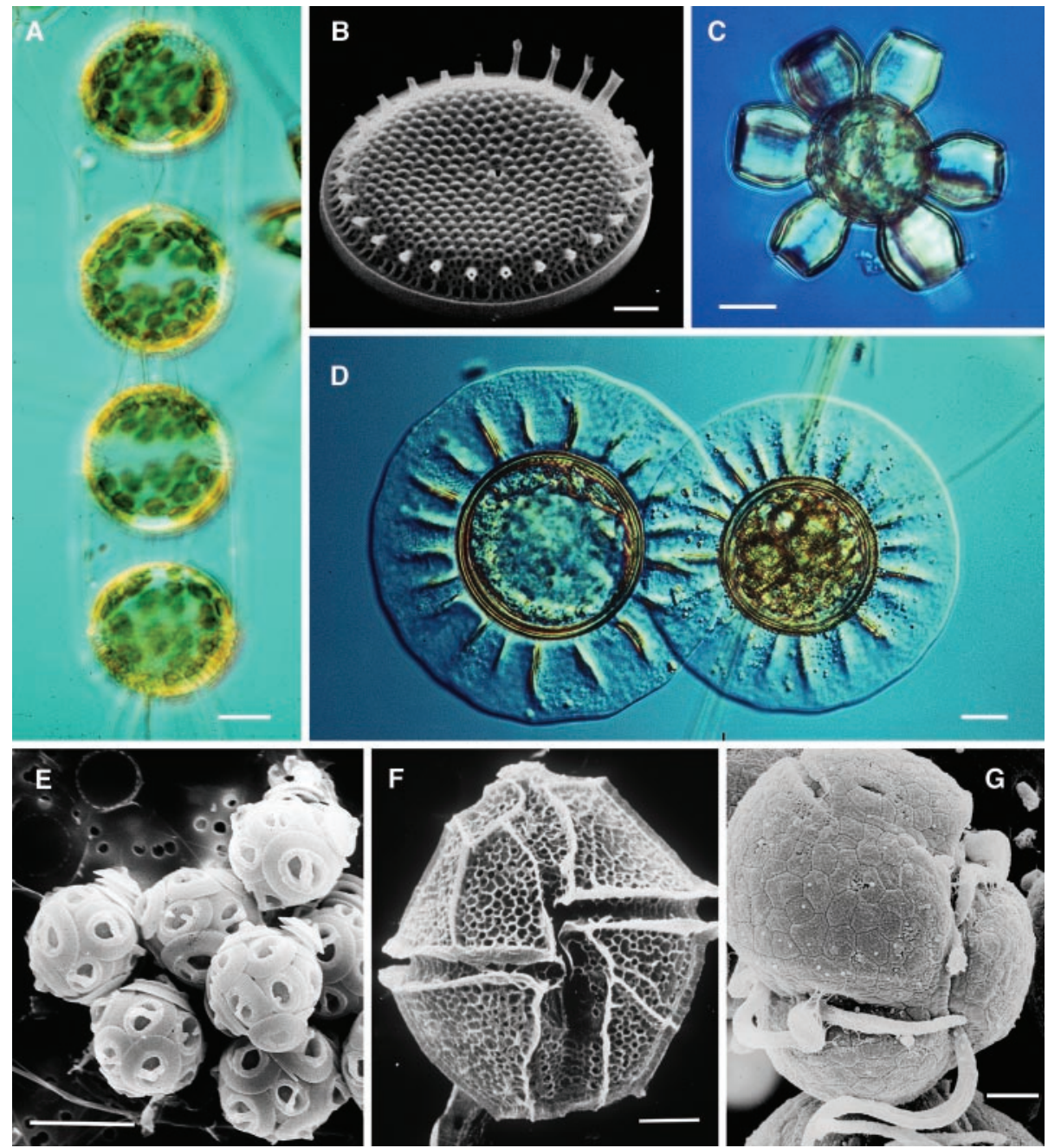

Fig. 1. Examples of representative marine eukaryotic phytoplankton. Light micrographs (Nomarski interference microscopy) of living cells, and scanning electron micrographs of dried and coated marine phytoplankton. (A) A chain of the diatom Stephanopyxis nipponica. (B) A single valve of the diatom Thalassiosira pacifica. (C) The large, tropical coccolithophore Scyphospahaera apsteinii. (D) An overlapping pair of phycomas of Pterosperma moebii. (E) A clump of coccospheres of Gephyrocapsa oceanica. (F) The athecate dinoflagellate Karlodinium micrum (= Gyrodinium galatheanum). (G) The thecate dinoflagellate Lingulodinium polyedra (flagella missing). Scale bars: (A, C, E, F) 10 $\mu \mathrm{m} ;(B$ and G) $2 \mu \mathrm{m}$; and (D) $25 \mu \mathrm{m}$. [Photographs: (A, C, D, F) F. J. R. Taylor; (B) E. Simons; (E) G. Hallegraeff; and (G) G. Gaines] 
the period the group had diversified throughout the oceans and into nonmarine environments $(37,38,38 a)$.

A bolide impact at the Cretaceous/Tertiary $(\mathrm{K} / \mathrm{T})$ boundary $(65 \mathrm{Ma})$ removed a major portion of the phytoplankton diversity that had developed over the preceding hundred million years, particularly among coccolithophorids (Fig. 3). Although the diversities of dinoflagellates and coccolithophorids recovered by the early Eocene $(\sim 55 \mathrm{Ma})$, they subsequently underwent a long-term decline that continues to the present. Among fossilizable taxa, modern dinoflagellate species diversity is comparable to that of the earliest Middle Jurassic levels, whereas modern coccolithophorid species diversity has dropped to levels last recorded in the Late Jurassic. In contrast, diatom diversity increased throughout the Cenozoic Era, concentrated in two major pulses, one at the Eocene/Oligocene boundary and one through the middle and late Miocene.

Thus, the fossil record suggests that dinoflagellates, coccolithophorids, and diatoms and their relatives came largely, but not completely, to displace other eukaryotic algae in the oceans from the Mesozoic to the present. The apparent displacement prompts three basic questions about the macroevolutionary patterns of marine phytoplankton: (i) Why have red plastids become incorporated into so many different host lineages? (ii) What process (or processes) selected for "red lineage" phytoplankton during the Mesozoic Era? (iii) What process (or processes) have been primarily responsible for the relative success of the three major "red lineage" phytoplankton taxa for the past 200 million years? To address such questions, we must draw insights about ecology and physiology from the comparative molecular biology of extant algal groups and interpret them in the context of changing environmental conditions inferred from the geological record.

\section{Ecological Reset in the Mesozoic Era}

The End-Permian mass extinction marked a major transition in ocean ecosystem structure. Relatively large carbon-isotope excursions, coupled with the deposition of extensive black shales in Early Triassic shelf sea settings, indicate that extensive anaerobic conditions were widespread during the extinction and persisted for several million years afterward (39-41). Why should "red lineage" groups have radiated at this time? First, beyond the likelihood that mass extinctions provided ecological opportunities for the establishment of new clades (42), there must have been selective advantages for heretofore heterotrophic cells to acquire and retain a plastid. The favored plastids largely (but not exclusively) descended from red algae and were retained in the new host cells once the oceans returned to oxic conditions.

Long-term euxinic conditions potentially lead to denitrification (43-45), thereby leav-

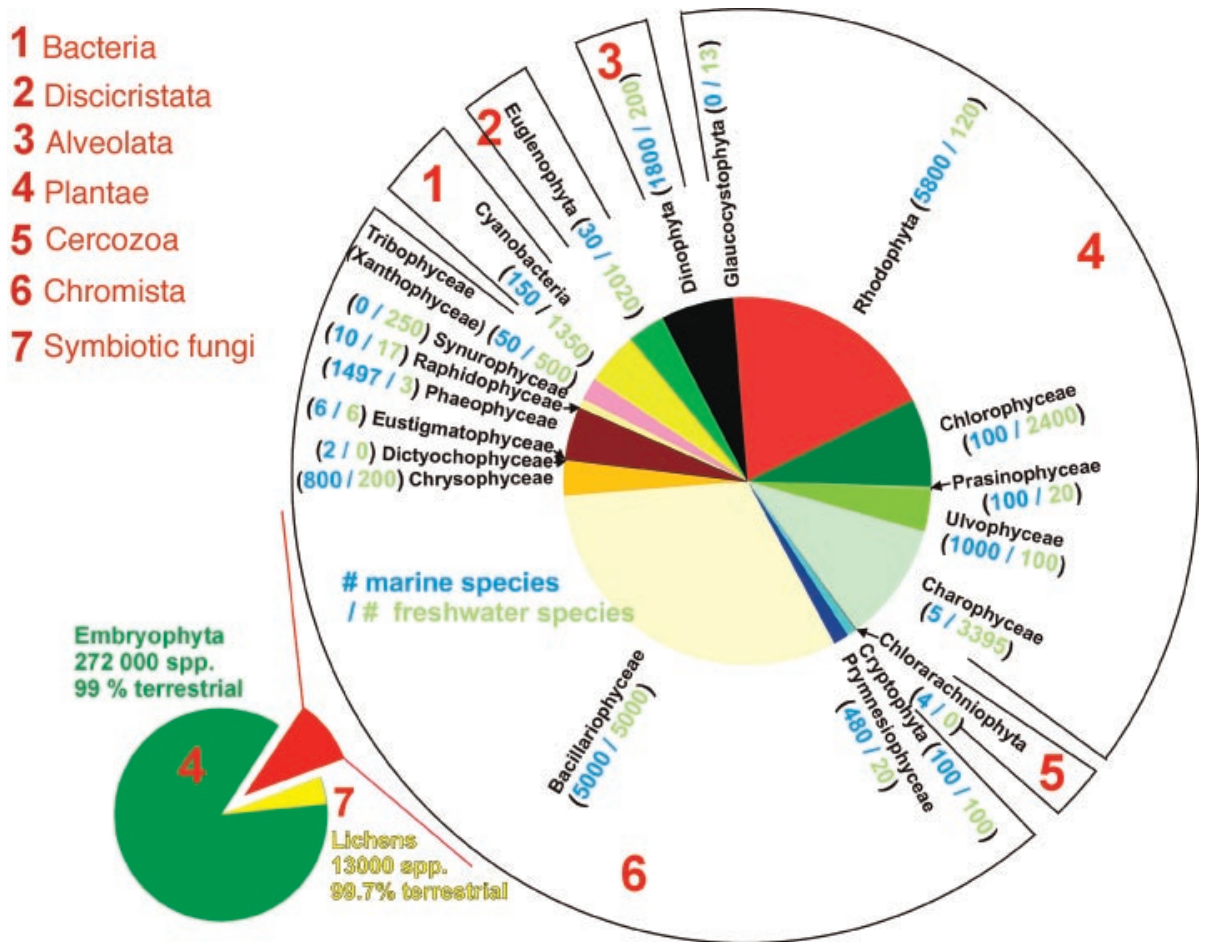

Fig. 2. A phylogenetic distribution of terrestrial and aquatic photoautrophs based on morphological characteristics. The deep phylogenetic diversity in aquatic photoautotrophs contrasts with that of terrestrial plants, which are overwhelmingly dominated by one clade (the Embryophytes). [Compiled from (1) and (85), drawn by C. de Vargas] ing the oceans impoverished for an essential macronutrient. Although photoautotrophic organisms would be physiologically limited by the paucity of fixed inorganic nitrogen, heterotrophs, which are the terminus of a bioenergetic cascade, would be severely affected. The acquisition of a plastid would potentially allow a heterotrophic organism to retain fixed nitrogen within the cell, while simultaneously obtaining organic carbon via photosynthesis. Indeed, many phytoplankton (dinoflagellates in particular) can assimilate and metabolize dissolved and even particulate organic material (46). This mixotrophic or "dual fuel" metabolism may have afforded an ecological advantage to a panoply of previously heterotrophic host cells during periods of ecosystem instability and reconstitution.

Trace-element chemistry, which is itself driven by hypoxic conditions, potentially and specifically selected for red plastids in the nascent host cells. The elemental composition of 29 species of marine phytoplankton from 10 taxonomic groups reveals that cyanobacteria and all eukaryotic members of the green plastid superfamily have inherently large iron, zinc, and copper quotas relative to those of red algae (rhodophytes) and all secondary red plastid symbionts (including red plastid-containing dinoflagellates, coccolithophorids, and diatoms; fig. S1). Members of the red lineage tend to have higher quotas for manganese, cobalt, and cadmium (47). These elemental preferences are consistent with the early ecological partitioning of green and red plastid lineages. The red plastid lineage proliferated in coastal benthic habitats, where consistently oxic conditions would have been first established, whereas green phytoplankton were more successful offshore, where seawater remained Fe-rich and comparatively $\mathrm{Zn}$ - and Cd-poor far longer (48-50). The genes responsible for the differences in the preferences of most trace elements within the organisms are no longer found in extant plastid genomes, but were transferred to the hostcell nuclear genome early in the evolutionary history of the symbiotic association $(51,52)$. Hence, the phenotypic manifestation of traceelement composition reflects selection pressures that occurred early in the evolution of the major phytoplankton taxa and predicts a highly conserved set of gene products that are specific to a plastid-inherited superfamily. These experimental results suggest that the phenotypic memory of trace-element composition of eukaryotic phytoplankton is related to redox history of the ocean.

In contrast to the long periods of suboxic conditions that characterize the Early Triassic, the relatively short-lived $(<1$ million years) Mesozoic Oceanic Anoxic Events (OAEs) had a minor impact on the overall evolutionary trajectories of eukaryotic phyto- 
plankton. Thus, it appears that persistent directional changes in marine environments, rather than transient changes in redox chemistry, were stronger influences on the radiation of eukaryotic phytoplankton once the red lineage garnered a secure ecological advantage in the Late Triassic. But what factor(s) contributed specifically to the success of the polyphyletic red lineage?

\section{Plastid Portability}

Why are all three of the major ecologically prominent members of the red lineage in the contemporary ocean derived from secondary rather than primary symbiotic associations? One clue is provided in the genomes of plastids. There are 200 or fewer proteincoding genes in primary plastids, and no plastid is capable of synthesizing all the components necessary for its photosynthetic functions or replication without genes in the host cell's nucleus. If the genomic content of extant primary plastids is representative of the genomic landscape throughout the Phanerozoic, a metabolically successful secondary symbiotic association would require the nascent host cell to salvage genes from the primary endosymbiont's nuclear genome. That phenomenon seldom occurs. Hence, plastids with inherently larger numbers of retained genes potentially would increase the probability of a metabolically successful transplant into an incipient host cell. Because the greatest fraction of gene losses in plastids occurs early in the symbiotic association (52), plastids that were appropriated as secondary symbionts later in an evolutionary trajectory would likely contain more genetic information and hence be more "transportable" (52).

Red plastids retain a complementary set of core genes that confer photosynthetic function to a host cell. For example, the genes en- coding both subunits of ribulose-1,5-bisphosphate carboxylase-oxygenase are located in red-plastid genomes, whereas the gene encoding the small subunit of this critical enzyme was transferred to the nucleus of the host cells in the green lineage. The relatively greater retention of critical metabolic genes in red plastids within a primary eukaryote potentially increased the probability that the red lineage would be transferred via secondary symbioses to a variety of new, phylogenetically diverse, heterotrophic host cells (Fig. 4). The secondary symbiotic associa- tions subsequently were accompanied by gene winnowing in the plastid.

\section{Competition Among the Red Taxa}

The historical patterns of diversity in the fossil records of dinoflagellates and coccolithophorids are roughly concordant, but contrast with that of diatoms (Fig. 3). The differences in patterns of diversity reflect ecological strategies that, in turn, reflect environmental selection (53). Many species of diatoms can form extensive blooms (54), and in the contemporary ocean, this group is responsible for $\sim 40 \%$ of the net primary

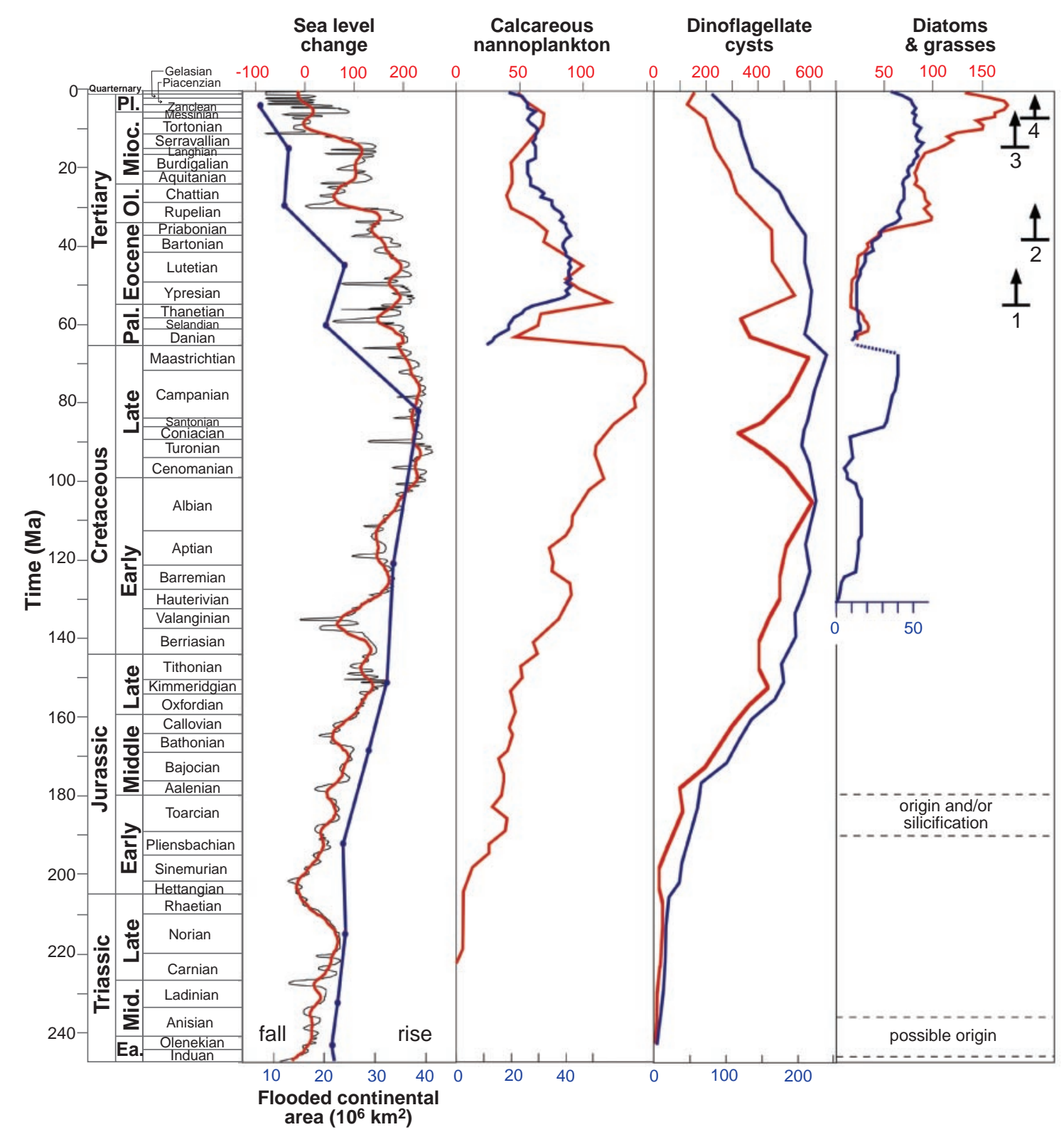

Fig. 3. Comparison of eukaryotic phytoplankton diversity curves (79) with sea-level change (red) (86), flooded continental areas (blue) (87), and the evolution of grasses. Phytoplankton species (red) diversities are from published studies [calcareous nannofossils (88); dinoflagellates (89); diatoms (90)]. Phytoplankton genus (blue) diversities were compiled for this study from public databases [calcareous nannofossils and diatoms (90); dinoflagellates (91)]. All records are adjusted to the Berggren et al. (92) (Cenozoic) and Gradstein et al. (93) (Mesozoic) time scales. Key to grass panel: (1) First conclusive occurrence of $C_{3}$ grass pollen $(94,95)$, phytoliths first appear in the marine record (75); $(2) C_{3}$ grasslands expand, phytolith diversity and abundance increase $(75,94)$; $(3)$ first macrofossil evidence of $C_{4}$ grass evolution $(94)$; (4) grassland expansion is coupled with a shift in dominance from $C_{3}$ to $C_{4}$ grasses $(75,77)$. 


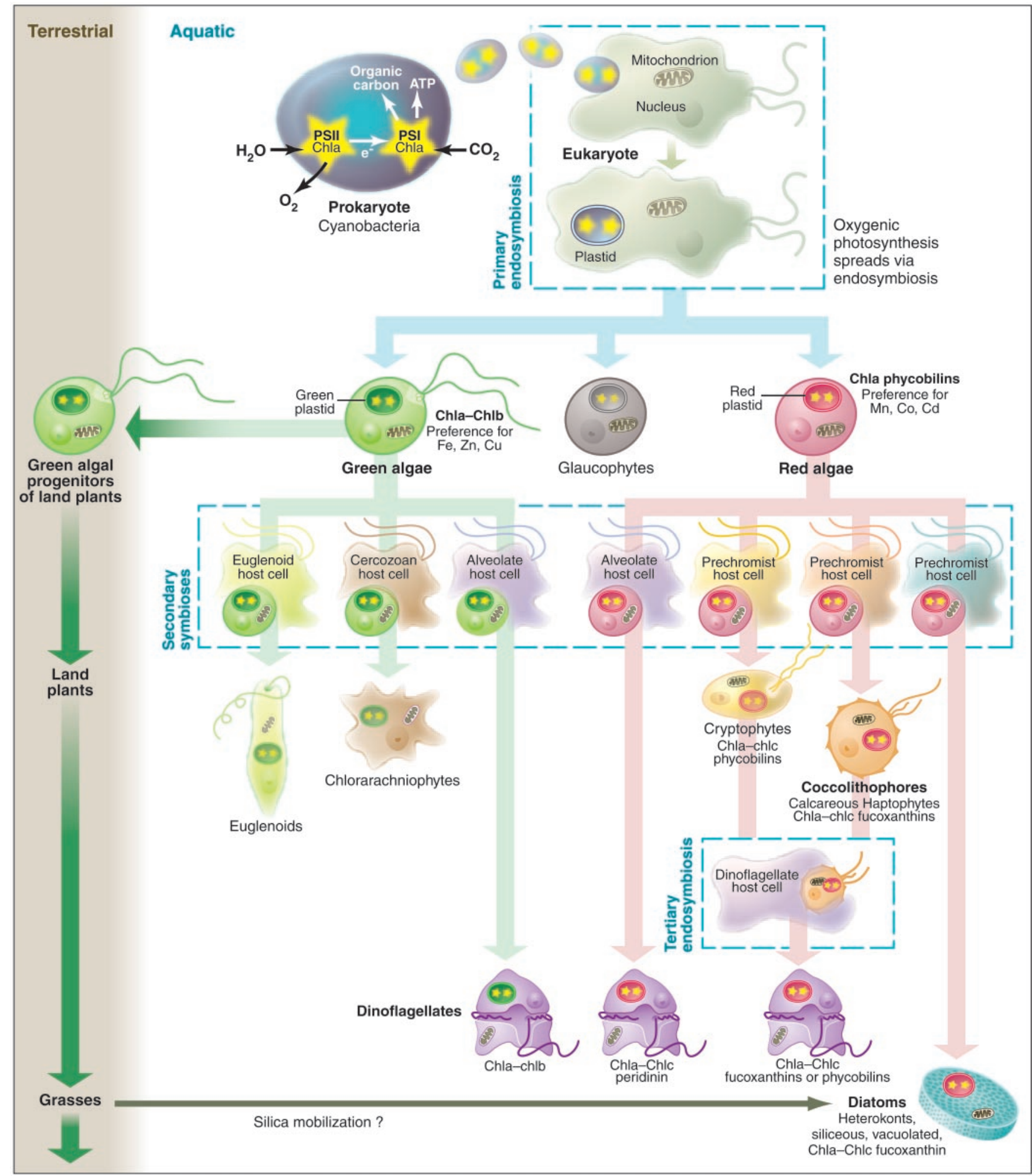

Fig. 4. The basic pattern of the inheritance of plastids in eukaryotic phytoplankton. The original plastid, derived from an ancestral cyanobacterium, was incorporated into a eukaryotic host cell via an endosymbiotic event to form a primary symbiotic oxygenic eukaryote. Three major extant clades decended from the primary symbiont: a "green" clade, a "red" clade, and glaucocystophytes. One branch of the green clade (the Charophyte algae) gave rise to land plants (Embryophytes), all of which are primary symbionts. Three secondary extant symbionts obtained green plastids from the primary symbiont lineage in association with three different host eukaryotic host cells. These secondary symbionts gave rise to Euglenophytes,
Chlorarachnophytes, and "green" dinoflagellates. The last contains very few living species and is not ancestral. Similarly, the red primary symbiont was incorporated in a variety of eukaryotic host cells to give rise to cryptophytes, haptophytes (including coccolithophorids), heterokonts (including diatoms), and peridinin-containing dinoflagellates. The last are, by far, the most abundant extant dinoflagellates. Three other dinoflagellate groups obtained plastids from tertiary symbiotic processes, where secondary photosynthetic symbionts were engulfed by a heterotrophic dinoflagellate host cell. The secondary symbionts include cryptophytes, haptophytes, and diatoms. In the contemporary ocean, most eukaryotic phytoplankton are secondary red symbionts. 
production and upward of $\sim 50 \%$ of the organic carbon exported to the ocean interior (55). In contrast to dinoflagellates and coccolithophores, pelagic (mostly centric) diatoms have evolved a nutrient storage vacuole. The vacuole occupies about $40 \%$ of the volume of the cell (56) and can retain sufficiently high concentrations of nitrate and phosphate such that a cell can undergo several divisions without the need for external macronutrients. Moreover, the storage vacuole allows diatoms to acquire and hoard short-term pulses of inorganic nutrients while simultaneously depriving competing groups of these essential resources. Consequently, diatoms thrive best in regions where nutrients are supplied with high pulse frequencies (57) such as coastal upwelling zones or highly turbulent areas of the open ocean (e.g., high-latitude seas).

In ecological simulation models that examine how nutrient resource acquisition strategies lead to competitive advantages [(e.g., (57-59)], diatoms inevitably outcompete other eukaryotic phytoplankton when frequent, highly turbulent conditions are punctuated by short periods of water-column stability. In contrast, coccolithophorids and dinoflagellates tend to dominate under relatively quiescent conditions. In theory, competitive exclusion could occur under extreme conditions, but it does not in the real ocean. The coexistence of three or more taxa representing thousands of morphologically defined species all competing for a few limiting resources is a consequence of the dynamic spatial and temporal heterogeneity of aquatic ecosystems that is maintained by physical processes $(60,61)$. Recognizing these fundamental differences in ecophysiology within the various phytoplankton groups, Margalef (62) proposed that competition among the three major redlineage taxa could be related to upper-ocean turbulence and the supply of nutrients.

The successional events predicting resource competition in dynamic (turbulent) environments are generally consistent with the patterns of diversity of dinoflagellates, coccolithophorids, and diatoms in the fossil record (63). The relatively warm Mesozoic was characterized by weak latitudinal thermal gradients (64), and consequently, globally averaged wind speeds and ocean thermohaline circulation probably were sluggish (65). This relatively quiescent period in the history of Earth's two major geophysical surface fluids favored coccolithophorids and dinoflagellates. With the onset of major polar ice caps about $33 \mathrm{Ma}$, wind speeds and thermohaline circulation became more vigorous, and upper-ocean turbulence increased $(66,67)$. These conditions favored diatoms. Although turbulence is clearly a selective agent in spatial and temporal ecological succession of phytoplankton in the contemporary ocean, is it the only factor that contributed to the evolutionary pattern inferred from the geological record of the three major eukaryotic groups?

\section{Coevolution of Terrestrial and Marine Ecosystems?}

Although resource competition partially can explain the relative success of the three major red phytoplankton groups, the rise of diatoms to ecological prominence in the Cenozoic requires further examination. Diatoms are virtually unique among extant photoautotrophic organisms in that they have an absolute requirement for silica $(68,69)$. Silica in the oceans is derived primarily from weathering of continental rocks and is delivered in soluble forms via rivers. On million-year time scales, continental elevation is a major factor in determining weathering fluxes of nutrients to the oceans (70), and throughout the Cenozoic, both orogeny and regression were important factors contributing to increased silica (and other nutrient) fluxes. However, there appears to be a remarkable concordance in timing of the radiations of diatoms in the fossil record and the evolution of terrestrial ecosystems, particularly the evolution of grasses (Fig. 3).

Like all land plants, grasses accelerate the weathering of silica. However, in contrast to most other terrestrial plants, up to $15 \%$ of the dry weight of grasses consists of opal phytoliths (micromineral deposits containing silica incorporated into cell walls). The solubility of opal phytoliths in water is twice that of abiotic mineral silicates (71-74). Despite Cretaceous origins, grasses remained sparse until the Eocene/Oligocene boundary (75), corresponding to a global climatic drying associated with the formation of extensive continental glaciation in the Antarctic. The expansion of grasses was accompanied by the coevolution of hypsodont (high crown) dentition of grazing ungulates, which came to partially displace brachydont (leaf-eating) browsing mammals (76). The evolution of ungulates coincides with the widespread distribution of the silica-rich phytoliths and grit in grassland forage, essentially accelerating the biologically catalyzed silicate weathering process. Hence, the coevolution on grasses and diatoms, first in the Paleogene and later in the middle to late Miocene, potentially is a causally driven correlation related to biogeochemistry of silica weathering $(75,77)$.

\section{Conclusions}

The geological record indicates that the three groups of marine eukaryotic phytoplankton that largely dominate the modern oceans evolved relatively recently in Earth's history. Their radiation changed both ecosystem structure and biogeochemical cycles in the oceans. The fossil record is inevitably incomplete. For example, in the contemporary oceans, higher trophic levels, such as fish and marine mammals, depend on short food chains driven by bloom-forming phytoplankton, which, in the modern ocean, is usually based on diatoms. The intermediaries in this energy transfer are metazoan zooplankton, such as copepods, which have virtually no fossil record. We can only infer that the rise of armored phytoplankton through the Mesozoic to the present represents an expansion in diversity of secondary and higher order food web dynamics. The long-term increase in metazoan diversity in marine ecosystems in the Cenozoic almost certainly is a partial reflection of adaptive evolution associated with a long-term rise to prominence of eukaryotic algae in pelagic ecosystems (78).

The impact of the expansion of red-lineage phytoplankton on the long-term carbon cycle is clearer. Between 200 and $20 \mathrm{Ma}$, there was an overall increase in $\delta^{13} \mathrm{C}$ values in both marine carbonates $\left(\delta^{13} \mathrm{C}_{\text {carb }}\right)(79)$ and organic carbon $\left(\delta^{13} \mathrm{C}_{\text {org }}\right)(80)$. The concurrent depletion of ${ }^{12} \mathrm{C}$ in both reservoirs requires an increase in the overall burial and sequestration of organic matter in the lithosphere. Our evolutionary analysis suggests that the increased burial was accompanied by shifts in phytoplankton community composition associated with increased storage capacity accompanying the opening of the Atlantic Ocean basin. The emergence of new eukaryotic phytoplankton groups that efficiently exported organic matter increased the efficiency of organic carbon burial beginning in the Early Jurassic. The net result appears to have contributed to a gradual depletion in $\mathrm{CO}_{2}$ from the oceanatmosphere system and a simultaneous increase in the oxidation state of Earth (79).

\section{References and Notes}

1. P. G. Falkowski, J. A. Raven, in Aquatic Photosynthesis (Blackwell Scientific, Oxford, 1997), p. 375.

2. C. Field, M. Behrenfeld, J. Randerson, P. Falkowski, Science 281, 237 (1998).

3. Structural and sequence analyses indicate that the reaction center of PSII is derived from purple nonsulfur bacteria, whereas that from PSI is derived from green sulfur bacteria, neither of which can split water to form oxygen (81).

4. J. A. Raven, P. G. Falkowski, Plant Cell Environ. 22, 741 (1999).

5. J. Farquhar, H. Bao, M. Thiemens, Science 289, 756 (2000).

6. A. Bekker et al., Nature 427, 117 (2004).

7. C. F. Delwiche, Am. Nat. 154, S164 (1999).

8. J. D. Palmer J. Phycol. 39, 4 (2003).

9. Ribosomal sequence homology and structural analysis of the cytochrome b/c1 complex in the mitochondrion suggests that the mitochondrion may itself have been derived from an endosymbiont closely related to extant purple nonsulfur photosynthetic bacteria, potentially conferring an ancestral anoxygenic photosynthetic pathway on the host-cell lineage (82-84)

10. N. J. Butterfield, Geol. Soc. Am. Abstr. Progr. 34, 169 (2002).

11. T. N. German, in Organic World One Billion Years Ago (Nauka, Leningrad, 1990), p. 52.

12. R. E. Summons, L. L. Jahnke, J. M. Hope, G. A. Logan, Nature 400, 554 (1999).

13. J. Brocks, R. Summons, in Treatise on Geochemistry W. H. Schlesinger, Ed. (Elsevier, Amsterdam, 2003), vol. 8, pp. 63-115.

14. M. Rosing, R. Frei, Earth Planet. Sci. Lett. 217, 237 (2004).

15. H. N. Tappan, in The Paleobiology of Plant Protists (Freeman, San Francisco, 1980), p. 1028 
16. N. J. Butterfield, Paleobiology 26, 386 (2000).

16a.H. S. Yoon, J. D. Hackett, C. Ciniglia, G. Pinto, D. Bhattacharya, Mol. Biol. Evol. 21, 809 (2004).

17. N. J. Butterfield, A. H. Knoll, K. Swett, Fossils Strata 34, 1 (1994).

18. G. Vidal, A. Knoll, Geol. Soc. Am. 161, 265 (1983).

19. K. Arouri, P. Greenwood, M. Walter, Org. Geochem. 30, 1312 (1999).

20. G. Colbath, H. Grenfell, Rev. Palaeobot. Palynol. 86 287 (1995).

21. N. Talyzina, M. Moczydlowska, Rev. Palaeobot. Palynol. 112, 1 (2000).

22. B. van de Schootbrugge et al., Paleobiology, in press

23. N. S. Fisher, R. L. Guillard, D. C. Bankston, J. Mar. Res. 49, 339 (1991).

24. J. Allen, Photosynth. Res. 36, 95 (1993)

25. Modern phycomas are rich in lipids and consequently buoyant; they can be found on beaches, where they are washed in by waves.

26. J. Moldowan, N. Talyzina, Science 281, 1168 (1998).

27. R. Fensome, J. Mar. Res. 49, 339 (1991).

28. R. A. Fensome, G. L. Williams, R. A. MacRae, J. M. Moldowan, F. J. R. Taylor, Paleobiology 22, 329 (1996).

29. J. R. Young, S. A. Davis, P. R. Bown, S. Mann, J. Struct. Biol. 126, 195 (1999).

30. T. J. Bralower, P. R. Bown, W. G. Siesser, Mar. Micropaleontol. 17, 119 (1991).

31. P. R. Bown, J. A. Lees, J. R. Young, in Coccolithophores-from Molecular Processes to Global Impact, H. Thierstein, J. R. Young, Eds. (Springer, Berlin, 2004), pp. 481-508.

32. M.-P. Aubry, in Late Paleocene-Early Eocene Climatic and Biotic Events in the Marine and Terrestrial Records, P. Aubry, S. Lucas, W. A. Berggren, Eds. (Columbia Univ. Press, New York, 1998), pp. 158-203.

33. W. Koositra, M. De Stefano, D. G. Mann, L. Medlin, Prog. Mol. Subcell. Biol. 33, 59 (2002).

34. A. Rothpletz, Z. Deutsch Geolog. Gesellsch. 48, 854 (1896).

35. R. Gersonde, personal communication.

36. D. M. Harwood, V. A. Nikolaev, in Siliceous Microfossils, C. D. Blome, P. M. Whalen, R. Katherine, Eds (Paleontological Society, Short Courses in Paleontology, 1995), vol. 8, pp. 81-106.

37. R. Gersonde, D. M. Harwood, Eds., Lower Cretaceous Diatoms from ODP Leg 113 Site 693 (Weddell Sea) Part I, Vegetative Cells, vol. 113 (Ocean Drilling Program, College Station, TX, 1990), Pp. 365-402.

38. E. Chacon-Baca, H. Beraldi-Campesi, S. R. S. CevallosFerriz, A. H. Knoll, S. Golubic, Geology 30, 279 (2002)

38a.J. S. S. Damste et al., Science 304, 584 (2004).

39. Y. Isozaki, Science 276, 235 (1997).
40. A. Knoll, R. Bambach, D. Canfield, J. Grotzinger, Science 273, 452 (1996)

41. P. B. Wignall, R. J. Twitchett Science 272, 1155 (1996)

42. R. K. Bambach, Paleobiology 19, 372 (1993).

43. P. Falkowski, Nature 387, 272 (1997).

44. A. D. Anbar, A. H. Knoll, Science 297, 1137 (2002).

45. K. Fennel, P. Falkowski, M. J. Follows, Am. J. Sci., in press

46. L. A. Zaslavskaia et al., Science 292, 2073 (2001).

47. A. Quigg et al., Nature 429, 291 (2003).

48. A. D. Anbar, A. H. Knoll, Science 297, 1137 (2002).

49. M. Whitfield, Adv. Mar. Biol. 41, 3 (2001).

50. Cyanobacterial groups that evolved chlorophyll b also inhabit pelagic marine environments.

51. C. Delwiche, Am. Nat. 154, S164 (2000).

52. D. Grzebyk, O. Schofield, C. Vetriani, P. G. Falkowski, J. Phycol. 39, 259 (2003).

53. P. G. Falkowski, E. A. Laws, R. T. Barber, J. W. Murray, in Ocean Biogeochemistry: A JGOFS Synthesis, M. J. R. Fasham, Ed. (Springer, Berlin, 2003), pp. 99-121.

54. V. Smetacek, Protist 150, 25 (1999).

55. R. Dugdale, F. Wilkerson, Nature 391, 270 (1998).

56. J. A. Raven, Adv. Bot. Res. Inc. Adv. Plant Pathol. 25, 59 (1997).

57. S. Tozzi, O. Schofield, P. G. Falkowski, Mar. Ecol. Prog. Ser. 274, 123 (2004)

58. D. Tillman, Ecology 58, 338 (1977).

59. J. P. Grover, Ecology 69, 408 (1988)

60. W. K. W. Li, Nature 419, 154 (2002)

61. D. Siegel, Limnol. Oceanogr. 43, 1133 (1998)

62. R. Margalef, in Excellence in Ecology, O. Kinne, Ed. (Ecology Institute, Oldendorf, Germany, 1997), p. 176.

63. M. Prauss, Gottinger Arb. Geol. Paläontol. 76, 1 (2000).

64. T. Crowley, G. North, in Paleoclimatology (Oxford Univ. Press, New York, 1991), pp. 349.

65. B. T. Huber, D. Hodell, C. Hamilton, Geol. Soc. Am. Bull. 107, 1164 (1995).

66. E. J. Barron, P. J. Fawcett, W. H. Peterson, D. Pollard, S. L. Thompson, Paleoceanography 10, 953 (1995).

67. M. A. Chandler, D. Rind, R. Ruedy, Geol. Soc. Am. Bul 104, 543 (1992).

68. A. Falciatore, M. R. d'Alcala, P. Croot, C. Bowler, Science 288, 2363 (2000)

69. Some freshwater chrysophytes also have siliceous scales and cysts.

70. Y. Huh, J. M. Edmond, Geochim. Cosmochim. Acta 63 , 967 (1999).

71. A. Alexandre, J.-D. Meunier, F. Colin, J.-M. Koud, Geochim. Cosmochim. Acta 61, 677 (1997).

72. F. Bartoli, Ecol. Bull. 35, 469 (1983).

73. G. J. Rapp, S. C. Mulholland, Phytolith Systematics: Emerging Issues (Plenum, New York, 1992)
74. D. J. Conley, Global Biogeochem. Cycles 16, 1121 (2002).

75. G. Retallack, J. Geol. 109, 407 (2001).

76. N. Janis, J. Damuth, in Evolutionary Trends, K. McNammara, Ed. (Belknap, London, 1990), pp. 301-345.

77. G. J. P. Retallack, Palaios 12, 380 (1997).

78. R. E. Martin, Lethaia 36, 179 (2003)

79. M. Katz et al., Annu. Rev. Ecol. Syst., in press.

80. J. M. Hayes, H. Strauss, A. J. Kaufman, Chem. Geol. 161, 103 (1999)

81. J. Raymond, O. Zhaxybayeva, J. P. Gogarten, S. Y. Gerdes, R. E. Blankenship, Science 298, 1616 (2002).

82. F. J. R. Taylor, Proc. R. Soc. London 240, 267 (1979).

83. F. J. R. Taylor, Ann. N.Y. Acad. Sci. 503, 1 (1987).

84. C. Esser et al., Mol. Biol. Evol., 10.1093/molbev/ msh200 (2004)

85. S. L. Bauldauf, Science 300, 1703 (2003)

86. B. U. Haq, J. Hardenbol, P. R. Vail, Hist. Biol. 4, 75 (1987).

87. A. B. Ronov, Am. J. Sci. 294, 777 (1994).

88. P. R. Bown, J. A. Lees, J. R. Young, in Coccolithophores-from Molecular Processes to Global Impact, H. Thierstein, J. R. Young, Eds. (Elsevier, Amsterdam, 2004).

89. L. E. Stover et al., in Palynology: Principles and Applications, J. Jansonius, D. C. McGregor, Eds. (American Association of Stratigraphic Palynologists Foundation, 1996), vol. 2, pp. 641-750.

90. C. Spencer-Cervato, Palaeontol. Electron. 2, 1 (1999). 91. MacRae, unpublished data.

92. W. A. Berggren, D. V. Kent, C. C. Swisher, M.-P. Aubry, Soc. Econ. Paleontol. Mineral. Spec. Publ. 54, 129 (1995).

93. F. M. Gradstein et al., Soc. Econ. Paleontol. Mineral. Spec. Publ. 54, 95 (1995).

94. B. F. Jacobs, J. D. Kingston, L. L. Jacobs, Ann. Mo. Bot. Gard. 86, 590 (1999).

95. E. Kellogg, Annu. Rev. Ecol. Syst. 31, 217 (2000)

96. Our research is supported by the National Science Foundation though the Biocomplexity Program under grant OCE-0083415. We thank Z. Finkel, A. Milligan, P. Olsen, D. Kent, K. Miller, M. Aubry, V. Smetacek, L. Graham, C. Delwiche, C. de Vargas, J. Grassle, P. Strother, S. Tozzi, Z. Dubinsky, E. Laws, and G. Retallack for discussions and comments.

Supporting Online Material

www.sciencemag.org/cgi/content/full/305/5682/354/ DC1

Fig. S1

References

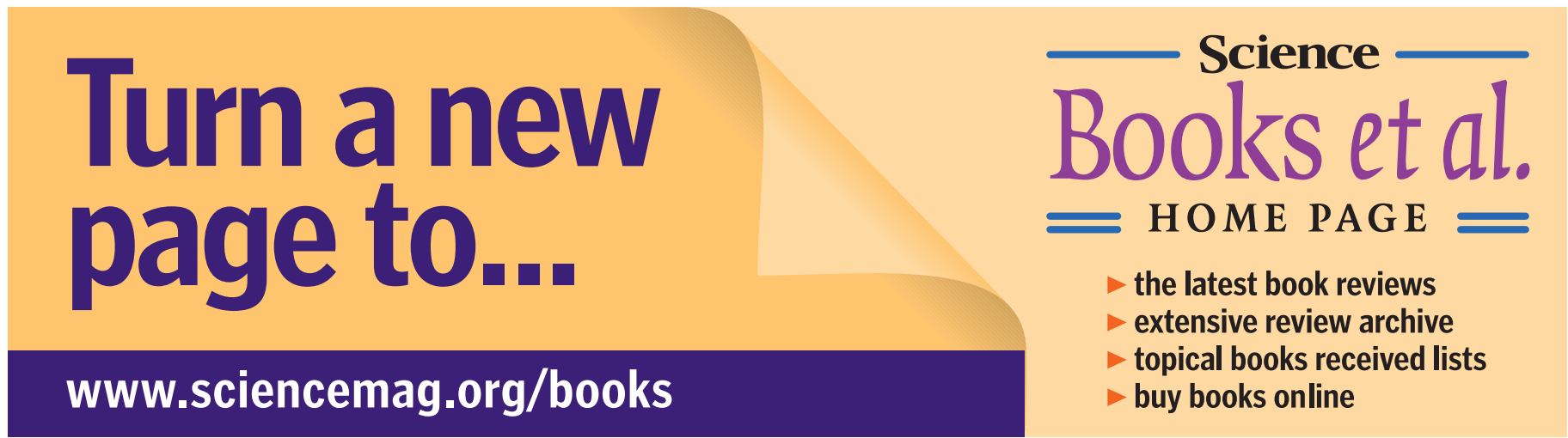

